Boletín de la Sociedad Geológica Mexicana

VOLUMEN 67, NÚM. 3, 2015, P. 433-446

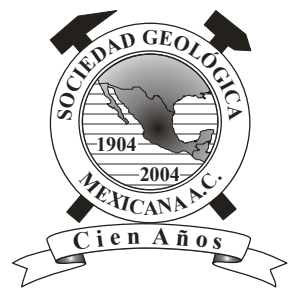

\title{
Laboratory synthesis of goethite and ferrihydrite of controlled particle sizes
}

\author{
Milton Villacís-García ${ }^{1}$, Mariana Ugalde-Arzate ${ }^{1}$, Katherine Vaca-Escobar ${ }^{1}$, Mario Villalobos ${ }^{1}{ }^{1 *}$, \\ Rodolfo Zanella², Nadia Martínez-Villegas ${ }^{3}$ \\ ${ }^{1}$ Environmental Bio-Geochemistry Group, Earth Sciences Graduate Program, Geochemistry Department, Instituto de Geología, \\ Universidad Nacional Autónoma de México (UNAM), Coyoacán, Ciudad Universitaria, México 04510, D.F. \\ ${ }^{2}$ Centro de Ciencias Aplicadas y Desarrollo Tecnológico, Universidad Nacional Autónoma de México (UNAM), Coyoacán, Ciudad \\ Universitaria, México 04510, D.F. \\ ${ }^{3}$ IPICyT, Instituto Potosino de Investigación Científica y Tecnológica, Camino a la Presa San José No. 2055, Col. Lomas 4a Secc., \\ 78216 San Luis Potosí, SLP, México. \\ *mar.villa@stanfordalumni.org
}

\begin{abstract}
Iron oxyhydroxides, such as goethite and ferrihydrite, are highly abundant and ubiquitous minerals in geochemical environments. Because of their small particle sizes, their surface reactivity is high towards adsorption of anions and cations of environmental relevance. For this reason these minerals are extensively studied in environmental geochemistry, and also are very important for environmental and industrial applications. In the present work, we report the synthesis and characterization of goethite and ferrihydrite of controlled particle sizes. It has been shown that surface reactivity of these minerals is highly dependent on crystal sizes, even after normalizing by specific surface area. In order to investigate the reasons for this changing reactivity it is necessary to work with reproducible particle sizes of these minerals. We investigated here the experimental conditions to synthesize goethite samples of four different specific surface areas: ca. 40, 60, 80 and $100 \mathrm{~m}^{2} \mathrm{~g}^{-1}$, through the controlled speed of hydroxide addition during hydrolysis of acid Fe(III) solutions. In the case of 2-line ferrihydrite, samples with two different particle sizes were prepared by changing the aging time under the $\mathrm{pH}$ conditions of synthesis $(\mathrm{pH}=7.5)$. The synthesized minerals were identified and characterized by: X-ray diffraction, $\mathrm{N}_{2}$ adsorption BET specific surface area, transmission electron microscopy, attenuated total reflectance Fourier transform infrared spectroscopy, and maximum $\mathrm{Cr}(\mathrm{VI})$ adsorption.
\end{abstract}

Keywords: synthesis, iron oxides, specific surface area, goethite, ferrihydrite, particle size.

Resumen

Los oxihidróxidos de hierro, como la goetita y ferrihidrita, son minerales altamente abundantes y ubicuos en ambientes geoquímicos. Su reactividad superficial es alta hacia la adsorción de aniones y cationes de relevancia ambiental dados sus pequeños tamaños de partícula. Por esta razón estos minerales son estudiados extensamente en geoquímica ambiental, y también son muy importantes en aplicaciones ambientales e industriales. En el presente trabajo reportamos la síntesis y caracterización de goetitas y ferrihidritas de tamaño de partícula controlado dado que se ha demostrado que su reactividad superficial es altamente dependiente de sus tamaños cristalinos, aún después de normalizar por su área superficial especifica. Para investigar las razones de estos cambios de reactividad es necesario trabajar con tamaños de particula reproducibles de estos minerales. Aquí presentamos las condiciones experimentales para sintetizar muestras de goetita de cuatro diferentes áreas superficiales especificas: ca. 40, 60, 80 y $100 \mathrm{~m}^{2} \mathrm{~g}^{-1}$, a través de la velocidad controlada de adición de hidróxido durante la hidrólisis de soluciones ácidas de Fe(III). En el caso de ferrihidrita de 2 líneas, se prepararon muestras con dos tamaños diferentes de partícula cambiando el tiempo de añejamiento bajo las condiciones 
de $p H$ de sintesis ( $p H=7.5)$. Los minerales sintetizados se identificaron y caracterizaron por: difracción de rayos $X$, área superficial especifica por adsorción de $N_{2}$ BET, microscopía de transmisión electrónica, espectroscopía de infrarrojo de transformada de Fourier con reflectancia total atenuada, y adsorción de Cr(VI) máxima.

Palabras clave: sintesis, óxidos de hierro, área superficial especifica, goetita, ferrihidrita, tamaño de partícula.

\section{Introduction}

Iron oxides, oxyhydroxides and hydroxides (henceforth referred to as "iron oxides" for simplicity) are widely distributed in soils, rocks, lakes, rivers, on the seafloor, air and in organisms (Adegoke et al., 2013). Because of their abundance and reactivity, these minerals play an important role and are extensively studied in numerous disciplines, including environmental science, geochemistry, geology, engineering and health sciences (Schwertmann and Cornell, 2007), in an attempt to understand their different physical, chemical and mineralogical properties. According to Guo and Barnard (2013) there are 14 species of iron oxides, ten of which occur in nature, the most abundant being goethite $(\alpha-\mathrm{FeOOH})$, hematite $\left(\alpha-\mathrm{Fe}_{2} \mathrm{O}_{3}\right)$ and magnetite $\left(\mathrm{Fe}_{3} \mathrm{O}_{4}\right)$, followed by ferrihydrite $\left[\mathrm{Fe}_{10} \mathrm{O}_{14}(\mathrm{OH})_{2}\right]$ (Michel et al., $2007)$, maghemite $\left(\gamma-\mathrm{Fe}_{2} \mathrm{O}_{3}\right)$ and lepidocrocite $(\gamma$ - $\mathrm{FeOOH})$. These iron oxides are responsible for the mobility and fate of numerous chemical species in soils and aquatic environments through adsorption processes, particularly onto goethite and ferrihydrite (Maji et al., 2008; Swedlund et al., 2009; Villalobos and Antelo, 2011) or through adsorption followed by reduction mechanisms as is the case of susceptible species on magnetite (Villacís-García et al., 2015).

The present work reports the laboratory procedures required for the synthesis of goethite and ferrihydrite of controlled particle sizes, and their essential characterization, especially focusing on their surface properties. This is important because both minerals have shown considerable changes in surface reactivity as a function of their particle size, often following trends that are non-intuitive or not easily predictable. Therefore, working with samples of controlled particle sizes is essential to ultimately understand the relationship between particle size and reactivity as a function of morphological and surface structural changes.

Goethite is an abundant constituent of terrestrial soils, sediments and oolitic iron ores, being a major weathering product of all rock types. It is predominant in younger sedimentary deposits, giving the rocks a yellow color (Prasad et al., 2006). Goethite particles show high specific surface areas and strong affinities for surface binding of oxyanions and heavy metals (Fendorf et al., 1997; Villalobos and Leckie, 2001; Antelo et al., 2005; Granados-Correa et al., 2011; Perelomov et al., 2011).

Synthetic goethite nanoparticles are acicular and often aggregated into bundles or rafts of oriented crystallites
(Varanda et al., 2002). The precipitation technique is probably the simplest and most efficient chemical pathway to obtain iron oxide particles. Iron oxides (goethite, magnetite or maghemite) are usually prepared by addition of alkali to iron salt solutions and keeping the precipitated solids in suspension for aging (Guyodo et al., 2003; Jaiswal et al., 2013).

In recent years, important differences in the reactivity of goethite have been found in an inverse relationship with its specific surface area (SSA). There appears to be two categories of goethite: ideal crystals with high specific surface area $\left(>80 \mathrm{~m}^{2} \mathrm{~g}^{-1}\right)$ that behave equally when adsorption data are normalized by SSA; and goethites of low specific surface area $\left(<80 \mathrm{~m}^{2} \mathrm{~g}^{-1}\right)$, which show progressively higher surface reactivity as SSA decreases (Villalobos and Perez-Gallegos, 2008). The controlled synthesis of goethites of desired SSAs is therefore useful to investigate this anomalous geochemical behavior, which is apparently caused by changes in the distribution of the goethite crystal faces exposed because some faces are considerably more reactive than others (Villalobos et al., 2009; Salazar-Camacho and Villalobos, 2010).

One of the most popular procedures for goethite preparation in the laboratory is the precipitation method proposed by Atkinson et al. (1967) and variations from it. The mechanisms of goethite formation involves deprotonation and hydrolysis of $\mathrm{Fe}$ (III) in solution, followed by nucleation and crystallization (Kosmulski et al., 2004). The length/width ratio of the crystals varies widely as a result of changes in precipitation conditions; for example, the crystal size of goethite decreased as the temperature fell from 70 to $4{ }^{\circ} \mathrm{C}$, increasing the specific surface area (SSA) by an order of magnitude (Schwertmann et al., 1985; Montes-Hernandez et al., 2011). Conversely, stirring conditions can promote the growth of goethite crystals (Schwertmann and Stanjek, 1998). More recently, the use of surfactants and other organic compounds for goethite synthesis has also been applied to control its size and shape (Zamiri et al., 2014).

However, it is clear that even small changes in one chosen method, such as the Atkinson et al. (1967) method, may have important repercussions on the resulting particle sizes, as evaluated by specific surface area (SSA). Table 1 shows a compilation of such changes with resulting SSA values varying from 8 to $105 \mathrm{~m}^{2} \mathrm{~g}^{-1}$. In the present work, we adopted the Atkinson et al. (1967) method and investigated the effect of base addition rate on the resulting goethite 
Table 1. Summary of conditions commonly employed in goethite syntheses.

\begin{tabular}{|c|c|c|c|c|c|c|}
\hline Reagents & Concentration & Condition & Aging & Cleaning & $\begin{array}{c}\mathrm{SSA}^{\mathrm{a}} \\
\left(\mathrm{m}^{2} \mathrm{~g}^{-1}\right) \\
\end{array}$ & Reference \\
\hline $\begin{array}{c}\mathrm{Fe}\left(\mathrm{NO}_{3}\right)_{3} \cdot 9 \mathrm{H}_{2} \mathrm{O} \\
\mathrm{KOH}\end{array}$ & $\begin{array}{c}50 \mathrm{~g} / 825 \mathrm{ml} \mathrm{H}_{2} \mathrm{O} \\
200 \mathrm{ml}(2.5 \mathrm{~N})\end{array}$ & $\begin{array}{l}\mathrm{OH}^{-} \text {addition } \\
\text { to } \mathrm{pH} 12\end{array}$ & $\begin{array}{l}\text { Heated } 60^{\circ} \mathrm{C} \\
\text { for } 24 \text { hours }\end{array}$ & Dialyzed & 70.9 & Atkinson et al ., 1967 \\
\hline $\begin{array}{c}\mathrm{Fe}\left(\mathrm{NO}_{3}\right)_{3} \cdot 9 \mathrm{H}_{2} \mathrm{O} \\
\mathrm{NaOH}\end{array}$ & $\begin{array}{c}450 \mathrm{~g} / 8.3 \mathrm{~L} \mathrm{H}_{2} \mathrm{O} \\
900 \mathrm{ml}(5 \mathrm{~N})\end{array}$ & $\begin{array}{l}\mathrm{OH}^{-} \text {addition } \\
\text { to } \mathrm{pH} 12\end{array}$ & $\begin{array}{l}\text { Heated } 60^{\circ} \mathrm{C} \\
\text { for } 24 \text { hours }\end{array}$ & Dialyzed & 45 & Van Geen et al ., 1994 \\
\hline $\begin{array}{c}\text { Fe nitrate } \\
\mathrm{NaOH}\end{array}$ & $\begin{array}{l}0.5 \mathrm{M} \\
2.5 \mathrm{M}\end{array}$ & $\begin{array}{c}\text { Slow } \\
\text { neutralizing to } \\
\text { pH } 12\end{array}$ & $\begin{array}{c}\text { Heated } 60^{\circ} \mathrm{C} \\
\text { for } 90-100 \text { hours }\end{array}$ & Dialyzed & 105 & $\begin{array}{l}\text { Hiemstra and van Riemsdijk, } \\
1996\end{array}$ \\
\hline $\begin{array}{c}\mathrm{Fe}\left(\mathrm{NO}_{3}\right)_{3} \cdot 9 \mathrm{H}_{2} \mathrm{O} \\
\mathrm{KOH}\end{array}$ & $\begin{array}{l}100 \mathrm{ml}(1 \mathrm{M}) \\
180 \mathrm{ml}(5 \mathrm{M})\end{array}$ & $\begin{array}{l}\mathrm{OH} \text { - addition } \\
\text { and dilution to } \\
2 \mathrm{~L}\end{array}$ & $\begin{array}{l}\text { Heated to } 68^{\circ} \mathrm{C} \\
\text { for } 2 \text { months }\end{array}$ & $\begin{array}{l}\text { Washed and } \\
\text { freeze dried }\end{array}$ & 7.9 & Weidler et al ., 1996 \\
\hline $\begin{array}{c}\mathrm{Fe}\left(\mathrm{NO}_{3}\right)_{3} \cdot 9 \mathrm{H}_{2} \mathrm{O} \\
\mathrm{NaOH}\end{array}$ & $\begin{array}{l}1 \mathrm{~mol} \\
4 \mathrm{~mol}\end{array}$ & $\mathrm{OH}^{-}$addition & $\begin{array}{l}\text { Heated } 60^{\circ} \mathrm{C} \\
\text { for } 24 \text { hours }\end{array}$ & $\begin{array}{l}\text { Neutralized } \\
\text { and Dialyzed }\end{array}$ & 70 & Villalobos and Leckie, 2001 \\
\hline $\begin{array}{c}\mathrm{Fe}\left(\mathrm{NO}_{3}\right)_{3} \cdot 9 \mathrm{H}_{2} \mathrm{O} \\
\mathrm{NaOH}\end{array}$ & $\begin{array}{c}4 \mathrm{~L}(0.1 \mathrm{M}) \\
800 \mathrm{ml}(5 \mathrm{M})\end{array}$ & $\mathrm{OH}^{-}$dropwise & $\begin{array}{l}\text { Heated } 60^{\circ} \mathrm{C} \\
\text { for } 72 \text { hours }\end{array}$ & Dialyzed & 70.8 & Antelo et al. , 2005 \\
\hline $\begin{array}{c}\mathrm{Fe}\left(\mathrm{NO}_{3}\right)_{3} \cdot 9 \mathrm{H}_{2} \mathrm{O} \\
\mathrm{NaOH}\end{array}$ & $\begin{array}{c}50 \mathrm{~g} / 825 \mathrm{ml} \mathrm{H}_{2} \mathrm{O} \\
200 \mathrm{ml}(2.5 \mathrm{~N})\end{array}$ & $\begin{array}{l}\mathrm{OH}^{-} \text {addition } \\
\text { to } \mathrm{pH} 12\end{array}$ & $\begin{array}{l}\text { Heated } 60^{\circ} \mathrm{C} \\
\text { for } 72 \text { hours }\end{array}$ & Washed & 27 & Zhang and Stanforth, 2005 \\
\hline
\end{tabular}

${ }^{\text {a }}$ As determined by the nitrogen-adsorption BET method.

SSA at fixed volumes, concentrations and other synthetic conditions; evaluating in tandem the reproducibility of the results.

In the case of ferrihydrite (FH), this nanomineral is precursor to the other prevalent $\mathrm{Fe}(\mathrm{III})$ oxide minerals, goethite and hematite (Schwertmann et al., 2004; Cudennec and Lecerf, 2006), which form by aggregated, oriented crystal growth of ferrihydrite nanoparticles (Burrows et al., 2013). However, ferrihydrite itself is widespread as suspended material in the aqueous fraction of soils and weathered rocks, in precipitates around cold and hot springs, especially those supporting iron-metabolizing bacteria, and in acid mine effluents, especially as they neutralize (Childs, 1992; Fortin and Langley, 2005).

In the goethite synthesis, ferrihydrite is the initial precipitate that results from the rapid hydrolysis of $\mathrm{Fe}(\mathrm{III})$ solutions, before aging to goethite at higher temperature. The crystal size and order of ferrihydrite are usually lower than those of any other Fe oxide except feroxyhyte and schwertmannite, and it is considered a nanomineral because its particle sizes range only from 2 to $9 \mathrm{~nm}$ (Hiemstra, 2013). For this reason ferrihydrite shows very broad and few X-ray diffraction (XRD) bands, and the two particular varieties of this mineral are named according to the number of XRD bands they show: 6 -line ferrihydrite shows $6-8$ broad peaks and a higher crystallinity, and 2-line ferrihydrite shows only two very broad peaks and a lower crystallinity, but a higher reactivity. In natural environments all forms of ferrihydrite are widespread usually as young Fe oxides, and they play an important role as active adsorbents as a result of their very high SSA (Schwertmann and Cornell, 2007). Nevertheless, the actual reactive SSA is not known because upon drying for the experimental BET nitrogen adsorption determination, ferrihydrite nanoparticles aggregate considerably and thus yield values that are considerably lower than those found under aqueous suspension conditions. To date, no experimental method has been devised to determine the SSA of ferrihydrite under aqueous conditions.

Some of the conditions imposed in synthetic procedures to obtain ferrihydrite are compiled in Table 2, but systematic work has not been performed to determine resulting particle sizes or SSAs as a function of experimental conditions.

We limited the present research to the controlled synthesis of 2-line ferrihydrites because the reactivity of the more crystalline 6-line variety is expected to be very different. Given the difficulties for accurate determinations of particle sizes and SSAs of ferrihydrite in aqueous suspension, we complemented TEM observations with indirect parameters related to surface reactivity differences.

\section{Materials and methods}

\subsection{Goethite synthesis.}

Goethite was synthesized following the basic protocol of Atkinson et al. (1967), to yield $8-9 \mathrm{~g}$ of goethite: 50 $\mathrm{g}$ of $\mathrm{Fe}\left(\mathrm{NO}_{3}\right)_{3} \cdot 9 \mathrm{H}_{2} \mathrm{O}$ (Sigma-Aldrich) were weighed and 
dissolved in $825 \mathrm{~g}$ of deionized water (Milli-Q). Water used for synthesis solutions was previously boiled and bubbled in $\mathrm{N}_{2}$ to eliminate $\mathrm{CO}_{2}$. Separately, $200 \mathrm{ml}$ of a $2.5 \mathrm{M} \mathrm{NaOH}$ (Sigma-Aldrich) $\mathrm{CO}_{2}$-free solution were prepared. This $\mathrm{NaOH}$ solution was poured over the $\mathrm{Fe}$ (III) solution under $\mathrm{N}_{2}$ flow, while continuously stirring. From the conditions compiled in Table 1 it was clear that similar $\mathrm{pH}$, aging times and temperatures produced goethites with important differences in SSA. The small goethite particles synthesized by Hiemstra and van Riemsdijk (1996) by slow addition of base gave us a clue about the importance of the speed of $\mathrm{NaOH}$ addition in the hydrolysis of aqueous $\mathrm{Fe}(\mathrm{III})$ and the resulting particle sizes, so we focused on this parameter for the current investigation. The speed of base addition into the $\mathrm{Fe}(\mathrm{III})$ solution, was inversely proportional to the resulting goethite SSA (Table 3). For example, for the lowest SSA obtained through this control parameter, the complete $\mathrm{NaOH}$ solution was added at once in the reactor, and for the highest SSA values, the base addition rate was $1 \mathrm{~mL} \mathrm{~min}^{-1}$. After final $\mathrm{NaOH}$ addition $(\mathrm{pH}>12)$, the stirring was maintained for $30 \mathrm{~min}$. The reactor was then placed in an oven at $60{ }^{\circ} \mathrm{C}$ for $24 \mathrm{~h}$, to allow the initial ferrihydrite precipitate to age to goethite. Goethite precipitates were repeatedly washed, shaken, and centrifuged. Dilute $\mathrm{HNO}_{3}$ was used to drop the $\mathrm{pH}$ to 7 for the initial washes. For the sequential washes, deionized water was used until a conductivity value of 0.1 $\mu \mathrm{S} \mathrm{cm}{ }^{-1}$ was obtained.

\subsection{Ferrihydrite synthesis.}

$100 \mathrm{~mL}$ of a $0.2 \mathrm{M} \mathrm{FeCl} \cdot 6 \mathrm{H}_{2} \mathrm{O}$ (Sigma-Aldrich) were prepared and placed in a $250 \mathrm{~mL}$ Nalgene flask. The solution was vigorously stirred while a $1 \mathrm{M} \mathrm{NaOH}$ solution was added relatively quickly to bring the $\mathrm{pH}$ to 6.5 ; the $\mathrm{NaOH}$ addition was continued dropwise until the $\mathrm{pH}$ reached a value of 7.5 (Schwertmann and Cornell, 2007; Li et al., 2011).
The resulting suspension was divided into two batches that were named FFh and AFh, for fresh and aged ferrihydrites, respectively. The former was immediately and repeatedly washed, centrifuged and decanted until the conductivity was about $10 \mu \mathrm{S} \mathrm{cm}^{-1}$ and freeze dried (dialysis was avoided in order to minimize further particle aging). The AFh batch was aged for $48 \mathrm{~h}$ at room temperature with continuous stirring, after which it was also washed and freeze-dried as above. Both products were stored as dry solids at room temperature.

\subsection{X-ray Diffraction Identification}

Goethite and ferrihydrite X-ray powder diffraction (XRD) analyses were performed using a Shimadzu - XRD6000 diffractometer equipped with a copper tube and a graphite monochromator. Samples were disaggregated with an agate pestle and mortar, and were mounted in aluminum holders and placed in the diffractometer. XRD patterns were collected in an angular range of $2 \Theta$ from $4^{\circ}$ to $70^{\circ}$ with a rate of $1^{\circ} \mathrm{min}^{-1}$. Phase identification was made with a PDF database using Shimadzu software.

\subsection{Attenuated Total Reflectance-Fourier Transform} Infrared (ATF-FTIR) Measurements

The goethite and ferrrihidryte dried samples were characterized using an infrared spectrometer NicoletIS10, THERMO-SCIENTIFIC with a diamond GladiATR accessory from PIKE Technology, using the Omnic 9 software, which allows IR analysis in a wavelength range between 450 and $4000 \mathrm{~cm}^{-1}$. For each analysis, a background of the free diamond crystal was collected and used to correct for the presence of the internal reflection element and air. A small quantity of each dry sample was placed over the diamond surface.

Table 2. Summary of synthesis conditions reported for 2-line ferrihydrite synthesis.

\begin{tabular}{|c|c|c|c|c|c|c|}
\hline Reagents & Concentration & Condition & Aging & Cleaning & $\begin{array}{c}\mathrm{SSA}^{\mathrm{a}} \\
\left(\mathrm{m}^{2} \mathrm{~g}^{-1}\right) \\
\end{array}$ & Reference \\
\hline $\begin{array}{c}\mathrm{Fe}\left(\mathrm{NO}_{3}\right)_{3} \cdot 9 \mathrm{H}_{2} \mathrm{O} \\
\mathrm{NaOH}\end{array}$ & $\begin{array}{c}0.1 \mathrm{M} \\
1 \mathrm{M}\end{array}$ & $\begin{array}{l}\mathrm{OH}^{-} \text {addition } \\
\text { to } \mathrm{pH} 8\end{array}$ & $\begin{array}{l}20^{\circ} \mathrm{C} \\
\text { for } 48 \text { hours }\end{array}$ & $\begin{array}{l}\text { Dialyzed and } \\
\text { freeze dried }\end{array}$ & 337 & Antelo et al ., 2010 \\
\hline $\begin{array}{c}\mathrm{Fe}\left(\mathrm{NO}_{3}\right)_{3} \cdot 9 \mathrm{H}_{2} \mathrm{O} \\
\mathrm{KOH}\end{array}$ & $\begin{array}{c}0.2 \mathrm{M} \\
1 \mathrm{M}\end{array}$ & $\begin{array}{l}\mathrm{OH}^{-} \text {addition } \\
\text { to } \mathrm{pH} 8\end{array}$ & for 10 days & $\begin{array}{l}\text { Dialyzed } 15 \\
\text { hours }\end{array}$ & $650^{\mathrm{b}}$ & Hofmann et al ., 2005 \\
\hline $\begin{array}{c}\mathrm{Fe}\left(\mathrm{NO}_{3}\right)_{3} \cdot 9 \mathrm{H}_{2} \mathrm{O} \\
\mathrm{KOH}\end{array}$ & $\begin{array}{c}40 \mathrm{~g} / 500 \mathrm{ml} \mathrm{H}_{2} \mathrm{O} \\
330 \mathrm{ml}(1 \mathrm{M})\end{array}$ & $\begin{array}{l}\mathrm{OH}^{-} \text {addition } \\
\text { to } \mathrm{pH} 7-8 \\
\text { Last } 20 \mathrm{ml}\end{array}$ & $\begin{array}{l}\text { Only vigorous } \\
\text { stiring and } \\
\text { centrifugation }\end{array}$ & $\begin{array}{l}\text { Dialyzed } \\
\text { rapidly and } \\
\text { Freeze dried }\end{array}$ & $200-320$ & $\begin{array}{l}\text { Schwertmann and Cornell, } \\
2007\end{array}$ \\
\hline $\begin{array}{c}\mathrm{FeC}_{6} \mathrm{H}_{5} \mathrm{O}_{7} \\
\mathrm{NH}_{3}\end{array}$ & $\begin{array}{c}500 \mathrm{ml}(0.3 \mathrm{M}) \\
10 \mathrm{M}\end{array}$ & $\begin{array}{c}20 \mathrm{NH}_{3} \text { drops } \\
\text { / min } \\
\text { Till pH } 12\end{array}$ & $\begin{array}{l}\text { Heated to } 90^{\circ} \mathrm{C} \\
\text { For } 24 \text { hours }\end{array}$ & $\begin{array}{l}\text { Filtered off, } \\
\text { washed and } \\
\text { dried }\end{array}$ & 175.8 & Rout et al ., 2012 \\
\hline
\end{tabular}

a As determined by the nitrogen-adsorption BET method.

${ }^{\mathrm{b}}$ Value used for surface complexation modeling purposes, but is not the experimental BET value. 
Table 3. Rate of $\mathrm{NaOH}$ addition and stirring used to obtain goethites of varying SSA.

\begin{tabular}{ccc}
\hline $\begin{array}{c}\text { Rate of addition } \\
\mathbf{N a O H}\end{array}$ & $\begin{array}{c}\text { Rate of stirring } \\
(\mathbf{r p m})\end{array}$ & $\begin{array}{c}\text { SSA obtained } \\
\left(\mathbf{m}^{\mathbf{2}} \mathbf{g}^{-\mathbf{1}}\right)\end{array}$ \\
\hline Immediate & $60^{\mathrm{b}}$ & $41.5 \pm 4$ \\
$10 \mathrm{ml} \mathrm{min}^{-1}$ & 200 & $64 \pm 2$ \\
$5 \mathrm{ml} \mathrm{min}$ & 200 & $83 \pm 2$ \\
$1 \mathrm{ml} \mathrm{min}$ & 200 & $101 \pm 5$
\end{tabular}

a Nitrogen adsorption BET values from replicates of three to five independent syntheses.

${ }^{\mathrm{b}}$ Stirring speed promotes particle disaggregation, and thus formation of small final particle sizes. $60 \mathrm{rpm}$ is the minimum speed for the suspension to rotate as a whole at this total volume, and which helps to yield larger particles

\subsection{Specific Surface Area (SSA) Determination.}

The specific surface areas (SSAs) of goethite and ferrihydrite were calculated by the Brunauer-Emmett-Teller (BET) method on a Quantachrome Autosorb 1. Before nitrogen adsorption, $200-250 \mathrm{mg}$ of the dry and (mortar-) dispersed solid powders were placed on a Quantrachrome $9 \mathrm{~mm}$ cell, and outgassed at $105{ }^{\circ} \mathrm{C}$ for $24 \mathrm{~h}$ to remove adsorbed water. Nitrogen adsorption isotherms were programmed with a 44 data point collection, of which the first 11 were used for SSA calculations by using a nonlinear least-squares regression method to fit the interval data in the experimental isotherms.

\subsection{Transmission electron microscopy (TEM).}

Transmission electron microscopy (TEM) images were obtained using a Tecnai G2 F30 S-Twin TEM instrument. The TEM operates at $300 \mathrm{kV}$ using a field emission gun in Schottky mode as an electron source. The samples for TEM analysis were prepared by placing $3 \mathrm{mg}$ of the dried (mortar-disaggregated) solid iron oxide in $10 \mathrm{~mL}$ of absolute ethanol, and ultrasonication for $45 \mathrm{~min}$ for goethite and $6 \mathrm{~h}$ for ferrihydrite. Four drops of the slurry were deposited on a holey-carbon-coated copper grid for analysis.

\section{7. $\mathrm{Cr}(\mathrm{VI})$ adsorption maxima.}

Maximum $\mathrm{Cr}(\mathrm{VI})$ adsorption was determined following the procedures reported by Mesuere and Fish (1992), Van Geen et al. (1994) and Villalobos and Pérez-Gallegos (2008). $50 \mathrm{~mL}$ of a $4 \times 10^{-3} \mathrm{M} \mathrm{Cr}(\mathrm{VI})$ solution were prepared from $\mathrm{K}_{2} \mathrm{Cr}_{2} \mathrm{O}_{7}$ (JT Baker) and placed in a high density polypropylene reactor to which the iron oxide solid was added to yield a concentration of $1.8 \mathrm{~g} \mathrm{~L}^{-1}$ for goethite, and $0.3 \mathrm{~g} \mathrm{~L}^{-1}$ for ferrihydrite. The ionic strength was fixed to 0.1 $\mathrm{M}$ with $\mathrm{NaClO}_{4}$ (Sigma-Aldrich) and the $\mathrm{pH}$ was fixed to
$\mathrm{pH} 4$ with diluted $\mathrm{HClO}_{4}$ (Sigma-Aldrich). The suspension was immersed in an ultrasonic bath for approximately $1 \mathrm{~min}$ to ensure an adequate disaggregation and dispersion of the solid. The suspension was then placed in an orbital shaker for $72 \mathrm{~h}$, but the $\mathrm{pH}$ of the suspension required frequent readjustments to $\mathrm{pH} 4$. This procedure was made at least in triplicate, but for the extreme SSA goethites it was done in replicates of 10 to 15 because we are particularly interested to continue working with these goethites. Aqueous $\mathrm{Cr}(\mathrm{VI})$ concentrations at equilibrium were analyzed by UV-visible spectroscopy after filtering appropriate suspension aliquots through $0.05 \mu \mathrm{m}$ nitrocellulose membranes. Using a standard curve of $5-70 \mathrm{mg} \mathrm{Cr}(\mathrm{VI}) \mathrm{L}^{-1}$ at $\mathrm{pH} 4$ direct colorimetric measurements were made at $\lambda=348 \mathrm{~nm}$ (Akiyama et al., 2003) using a Jenna-Analytics SPECORD 210 PLUS Uv/ Vis spectrophotometer (detection limit $=0.3 \mathrm{mg} \mathrm{L}^{-1}$ ). The difference from the total $\mathrm{Cr}(\mathrm{VI})$ added initially was assumed to be the maximum adsorbed $\mathrm{Cr}(\mathrm{VI})$ concentration.

\section{Results and Discussion}

\subsection{Goethite synthesis}

Figure 1 shows photographs of the experimental set-up (a) and products obtained (b-c) during goethite synthesis in which $\mathrm{CO}_{2}$ exclusion was maintained throughout the high$\mathrm{pH}$ stages of the aqueous suspensions. The initial precipitate formed was a dark red suspended ferrihydrite, which upon aging turned to an ochre color goethite suspension. The different goethites varied from darker color hues for the high-SSA samples to lighter hues for the low-SSA samples.

\subsection{Goethite characterization.}

\subsubsection{Specific surface area (SSA)}

SSA is used in this work as a proxy for particle size. Goethite particles are acicular, or recently described more accurately as blades or laths (Livi et al., 2013), and thus, an average size parameter is difficult to define and measure directly. However, we may use the log-linear relationship between SSA and the geometric average particle size [eq. (1)] as an alternative method to report changes in particle sizes for goethite, based solely on SSA:

$$
\log \mathrm{SSA}=\log (k / \delta)-\log r
$$

Where $k$ is a constant related to the particle shape, $\delta$ is the specific gravity of the solid, and $r$ is an average size parameter (Parks, 1990). For highly symmetrical shapes, such as spheres or cubes, $k=3$ and $r$ is the sphere radius or the radius of the cube sides; but the $k$ value for the goethite lath is unknown. Since both $k$ and $\delta$ are expected to be approximately constant with goethite size changes, SSA changes are sufficient to indicate particle size differences in our samples, and no further efforts were devoted to calculate actual size values.

Table 3 shows the SSA values obtained for four different 

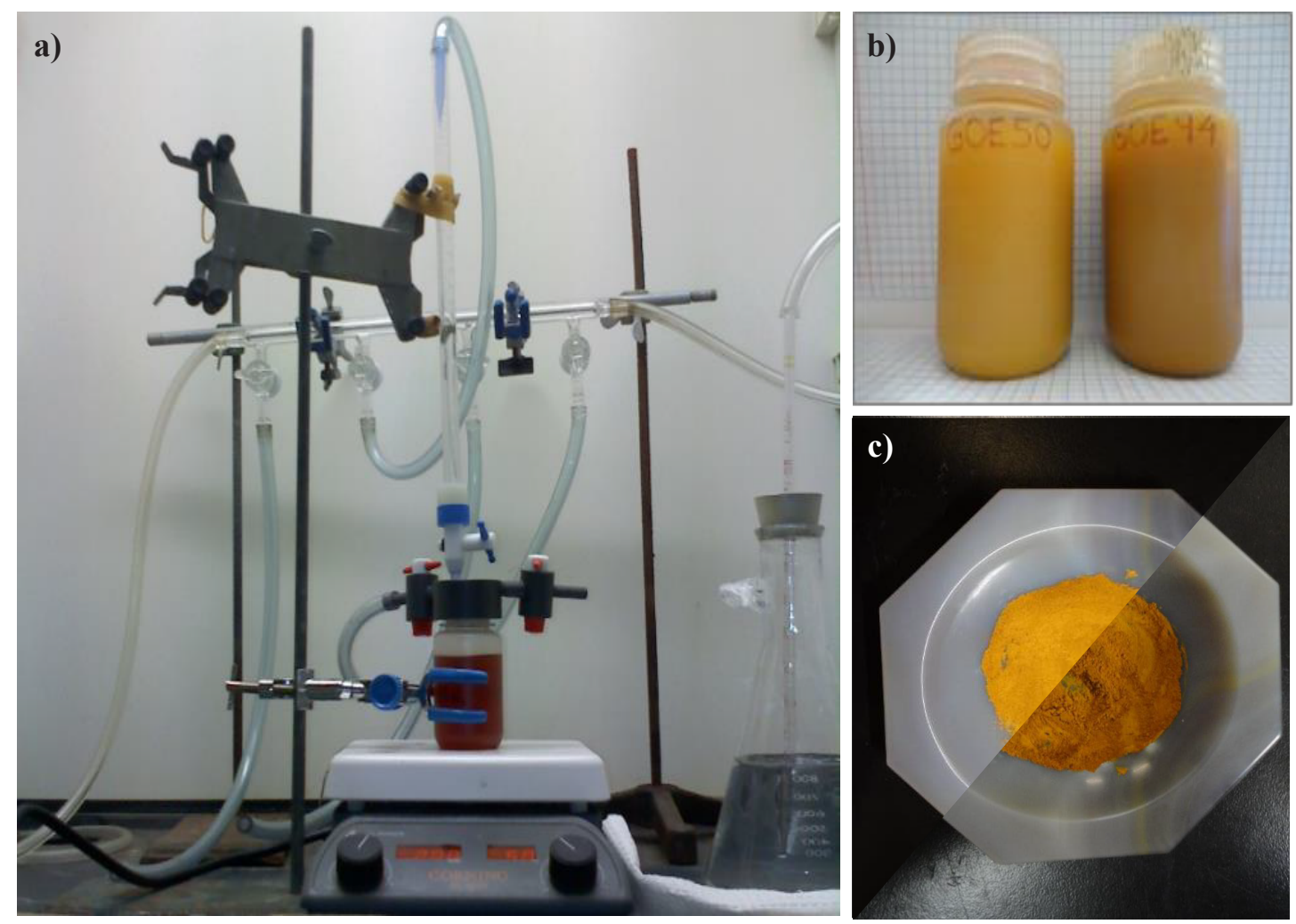

Figure 1. a) Experimental set-up for goethite synthesis showing fresh ferrihydrite precipitate after $\mathrm{NaOH}$ addition; b) Goethites obtained after aging: GOE50-labelled on the left corresponds to GOE43, and GOE94-labelled on the right to GOE101; c) clean and dried goethite (GOE43/GOE101) dispersed with mortar.

$\mathrm{NaOH}$ rate additions during goethite synthesis, ranging from $42 \mathrm{~m}^{2} / \mathrm{g}$ to $105 \mathrm{~m}^{2} / \mathrm{g}$, as additions of $2.5 \mathrm{M} \mathrm{NaOH}$ were gradually slowed down from an instantaneous addition of the $200 \mathrm{~mL}$ to $1 \mathrm{~mL} \mathrm{~min}^{-1}$ (i.e., to $3.33 \mathrm{~h}$ to add the $200 \mathrm{~mL}$ ), respectively. These values indicate that goethite particle laths are progressively smaller as the $\mathrm{NaOH}$ addition rate is decreased.

\subsection{2. $X$-ray diffraction (XRD)}

The XRD patterns of all samples synthesized correspond to pure goethite according to the JCPDS PDF database (JCPDS 29-713) used for phase identification, and no other Fe oxide phases were identified (Figure 2). The samples were analyzed under the same diffractometer conditions. Differences in their relative crystallinities may be observed from changes in the peak widths and heights. Sharper and taller peaks, denoting higher crystallinity, are observed as SSA decreases, except when going from the 101 to the 83 $\mathrm{m}^{2} \mathrm{~g}^{-1}$ goethites, which seem to show very similar peak widths and heights.

\subsubsection{Transmission electron microscopy (TEM)}

TEM images are shown for the two extreme sizes of goethites synthesized: GOE101 and GOE43 (Figure 3). In both cases the typical goethite lath shapes may be identified. GOE101 shows small ideal nanocrystals of lengths between
100 and $200 \mathrm{~nm}$ and widths of approximately $50 \mathrm{~nm}$ (Figure $3 \mathrm{a}$ and $\mathrm{b}$ ). GOE43 shows particles that seem to have grown in aggregated form, reaching $1 \mu \mathrm{m}$ lengths with widths of around $200 \mathrm{~nm}$ (Figure 3c and d).

\subsubsection{Attenuated Total Reflectance-Fourier Transform Infrared (ATR-FTIR) Spectroscopy}

The main ATR-FTIR spectra (Figure 4) are similar among all goethites. The peaks found at $621-632 \mathrm{~cm}^{-1}$ are associated to the $\mathrm{FeO}_{6}$ octahedral lattice (Ruan et al., 2001). The peaks at $786-791 \mathrm{~cm}^{-1}$, and at $886-897 \mathrm{~cm}^{-1}$ are assigned to $\mathrm{Fe}-\mathrm{O}-\mathrm{H}$ bending vibrations (Montes-Hernandez et al., 2011; Zamiri et al., 2014). There is a small peak around $1650 \mathrm{~cm}^{-1}$ that corresponds to bending modes of hydroxyl (Prasad et al., 2006). The broad peaks centered around $3101-3118 \mathrm{~cm}^{-1}$ correspond to the stretching of goethite hydroxyls and surface $\mathrm{H}_{2} \mathrm{O}$ molecules (Prasad et al., 2006). In the goethite sample with SSA of $43 \mathrm{~m}^{2} \mathrm{~g}^{-1}$ the presence of leftover $\mathrm{NO}^{3-}$ from incomplete washing may be detected at around $1400 \mathrm{~cm}^{-1}$.

A close-up of the region between $1200-1700 \mathrm{~cm}^{-1}$ (Figure 5), shows the presence of adsorbed water bending vibrations at $1651-1654 \mathrm{~cm}^{-1}$, and of adsorbed carbonate with peaks of the asymmetric and symmetric $\mathrm{O}-\mathrm{C}-\mathrm{O}$ stretch vibrations at $1499-1509 \mathrm{~cm}^{-1}$ and $1307-1322$ $\mathrm{cm}^{-1}$, respectively (Villalobos and Leckie, 2001). The 
adsorbed nitrate on GOE43 (Figure 5a) blocked the potential carbonate peaks on this sample.

\subsection{5. $\mathrm{Cr}(\mathrm{VI})$ adsorption}

Maximum chromate adsorption was evaluated at $\mathrm{pH}$ 4 (Table 4). The results show that the goethite with the lowest SSA (GOE43) has the highest adsorption capacity $\left(4.4 \mu \mathrm{mol} \mathrm{m}{ }^{-2}\right)$, while the other three goethites don't show much differences in adsorption capacities, between 2.8 and $3.0 \mu \mathrm{mol} \mathrm{m}{ }^{-2}$. These latter values are slightly larger than the $\mathrm{Cr}$ (VI) adsorption maximum reported previously for a 94 $\mathrm{m}^{2} \mathrm{~g}^{-1}$ goethite of $2.6 \mu \mathrm{mol} \mathrm{m} \mathrm{m}^{-2}$ under the same conditions (Villalobos and Perez-Gallegos, 2008). However the latter reported a considerably larger $\mathrm{Cr}(\mathrm{VI})$ adsorption maximum of $8.1 \mu \mathrm{mol} \mathrm{m} \mathrm{m}^{-2}$ for a $50 \mathrm{~m}^{2} \mathrm{~g}^{-1}$ goethite, suggesting that the increase in reactivity for the more reactive goethites may not be a sole function of SSA. The increase in surface reactivity of large goethites is related to a higher proportion of crystal faces that contain a larger value of reactive surface site density (Villalobos et al., 2009; Salazar-Camacho and Villalobos, 2010).

\subsection{Ferrihydrite synthesis}

The experimental set-up for ferrihydrite synthesis is very similar to that described in the goethite section. Samples of 2-line ferrihydrite were synthetized according to one variation of the method of Schwertmann and Cornell (2007), adding carefully $1 \mathrm{M} \mathrm{NaOH}$ to $100 \mathrm{~mL}$ of $0.2 \mathrm{M} \mathrm{FeCl}_{3}$ until $\mathrm{pH} 7.5$ with continuous stirring (Schwertmann and Cornell, 2007; Li, et al., 2011). To obtain different particle sizes the predominant experimental variable is $\mathrm{pH}$, and higher values produce surface charges that bring on growth by oriented aggregation (Burrows et al., 2013). Therefore, the longer the product remains in its synthesis medium rich in $\mathrm{OH}$ - groups, the greater the resulting particle size.

After the synthesis, products were repeatedly centrifuged and washed to remove the remaining salts. In this step, indirect evidence of different resulting particle size was observed, as presumably larger AFh particles were easily separated from the solution, in contrast to FFh particles. Furthermore, the final products had slightly different colors, AFh being the darkest.

\subsection{Ferrihydrite characterization}

\subsubsection{Specific Surface Area (SSA)}

Experimental BET results showed that the fresh ferrihydrite (FFh) had a higher SSA $\left(311 \mathrm{~m}^{2} / \mathrm{g}\right)$ than the aged ferrihydrite (AFh) $\left(258 \mathrm{~m}^{2} / \mathrm{g}\right)$. The uncertainties for

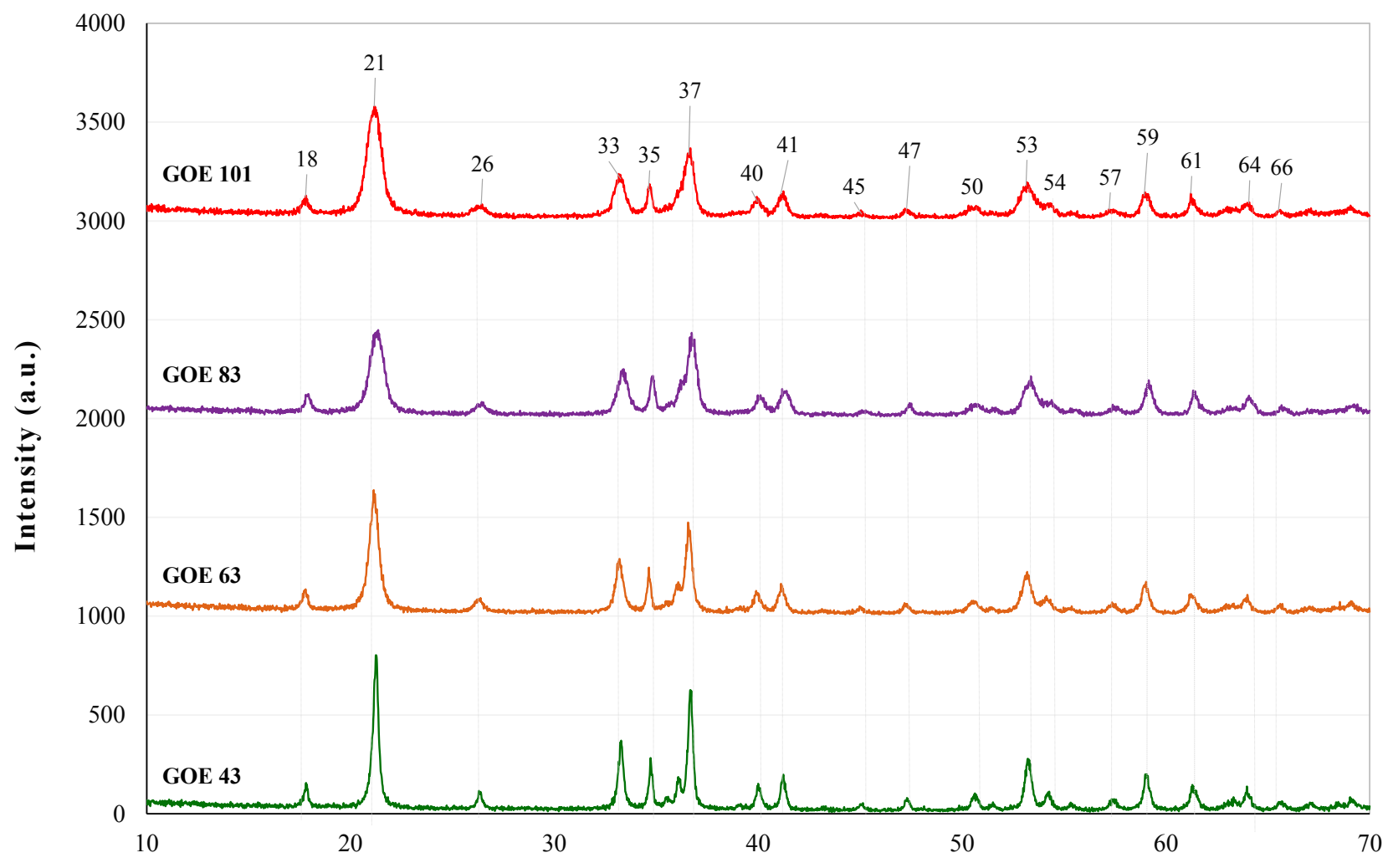

2 Theta (degrees)

Figure 2. XRD patterns of goethite samples of different SSAs. 

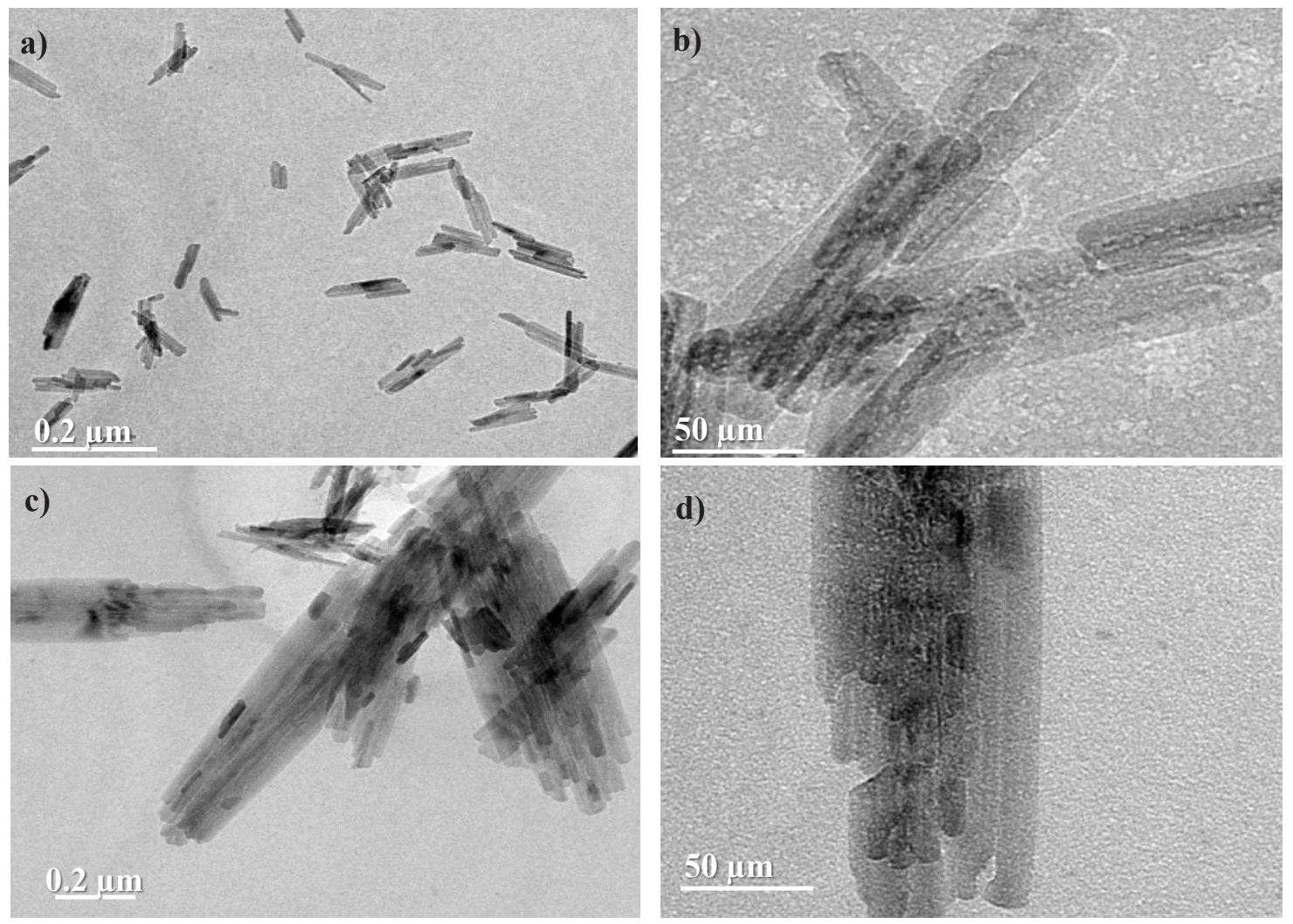

Figure 3. TEM images of GOE101 a) and b), and GOE43 c) and d), at two different magnifications.

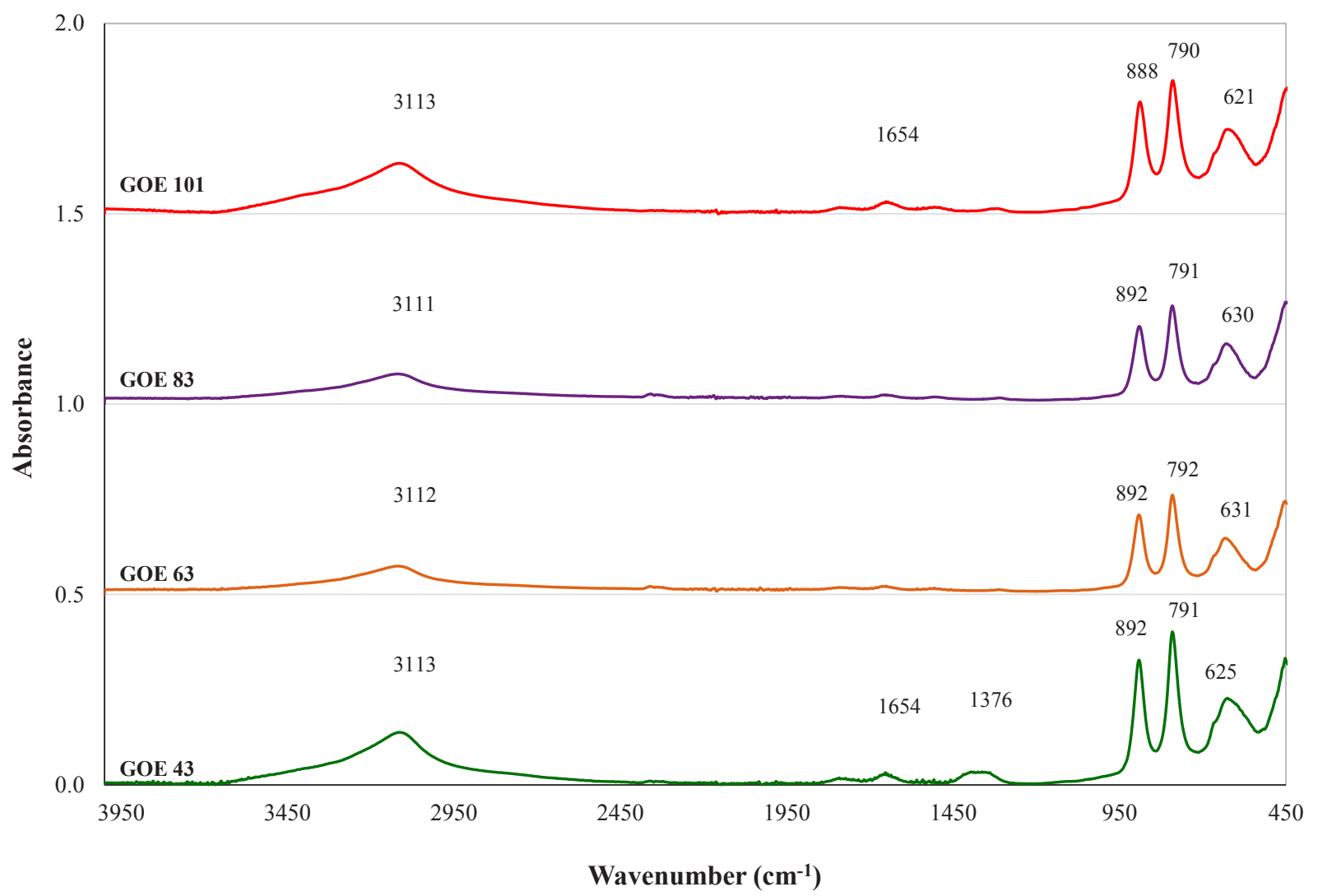

Figure 4. ATR-FTIR goethite measurements (complete spectra). 

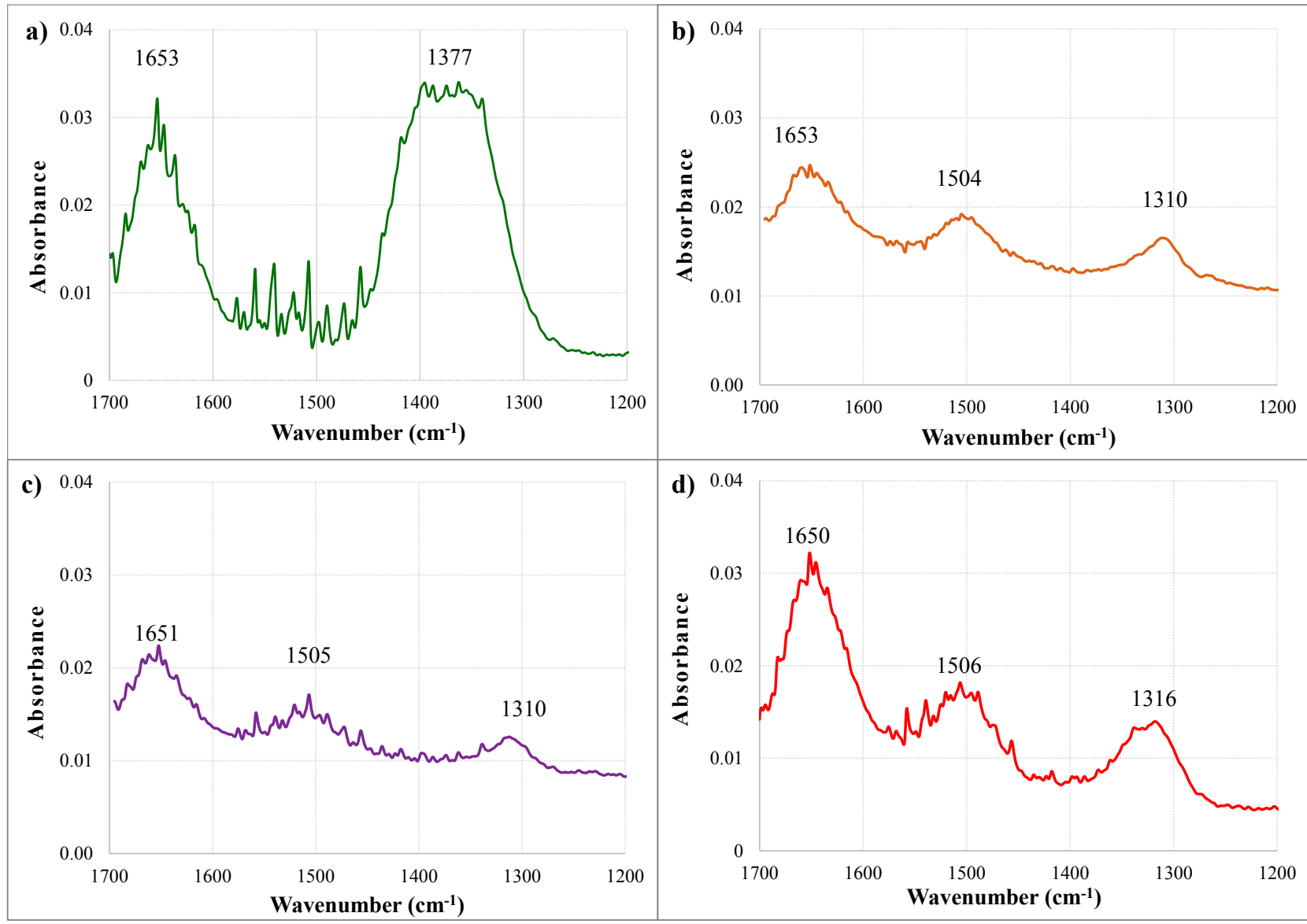

Figure 5. ATR-FTIR spectra amplified in the range between 1200 and $1700 \mathrm{~cm}^{-1}$ for a) GOE 43, b) GOE 63, c) GOE 83, and d) GOE 101 .

Table 4. Maximum $\mathrm{Cr}(\mathrm{VI})$ adsorption onto goethite. $[\mathrm{Cr}(\mathrm{VI})]$ initial $=4 \mathrm{x}$ $10^{-3} \mathrm{M}, \mathrm{I}=0.1 \mathrm{M} \mathrm{NaClO}_{4}$ at $\mathrm{pH} 4$.

\begin{tabular}{|c|c|c|}
\hline Sample & $\begin{array}{c}\mathrm{SSA}^{\mathrm{a}} \\
\left(\mathrm{m}^{2} \mathrm{~g}^{-1}\right)\end{array}$ & $\begin{array}{c}\operatorname{Cr}(\mathrm{VI}) \\
\left.(\mu \mathrm{mol} \mathrm{m})^{-2}\right)\end{array}$ \\
\hline GOE 43 & 42.7 & $4.39 \pm 0.27$ \\
\hline GOE 63 & 62.6 & $3.03 \pm 0.28$ \\
\hline GOE 83 & 83.3 & $2.87 \pm 0.21$ \\
\hline GOE 101 & 101.1 & $2.89 \pm 0.035$ \\
\hline
\end{tabular}

${ }^{a}$ The experimental error in the SSA determination by nitrogen adsorption BET measurements, for any individual goethite batch is $2-3 \mathrm{~m}^{2} \mathrm{~g}^{-1}$.

these determinations were $\pm 5 \mathrm{~m}^{2} / \mathrm{g}$.

Nevertheless, it is widely believed that SSA determined from dry samples of ferrihydrite considerably underestimates the actual SSA under aqueous suspension conditions, because of the high aggregation expected upon drying from such small nanoparticles (Villalobos and Antelo, 2011). Therefore, the previous values are only indicative of SSA of dry Fh aggregates.

\subsubsection{X-ray Diffraction ( $X R D)$}

The identity of the synthesis products was confirmed by XRD (Figure 6), showing almost identical patterns for both FFh and AFh, with the two bands characteristic of two-line ferrihydrite centered at $2 \theta$ of 35 and $63^{\circ}$ (Schwartmann and Cornell, 2007). Perhaps the only difference observed is a slightly taller band at $35^{\circ}$ for the aged sample. This would mean that the width of this peak at mid-height would be slightly lower, which is coincident with an expected larger crystal size of the aged sample. These differences, however, are too small to be analyzed quantitatively.

\subsubsection{Particle Size}

The TEM images for these samples show the extreme state of aggregation despite the attempts to disaggregate them using ultrasound for extended periods (6 h) (Figure 7). Close-ups of the border regions of aggregates show an important difference between both samples. For AFh (Figure 7a) particles of approximately $5 \mathrm{~nm}$ may be detected, in contrast to FFh (Figure 7b), where particle size seems to be around $2 \mathrm{~nm}$.

Because of this extreme particle aggregation, direct and accurate particle size measurements in ferrihydrites 


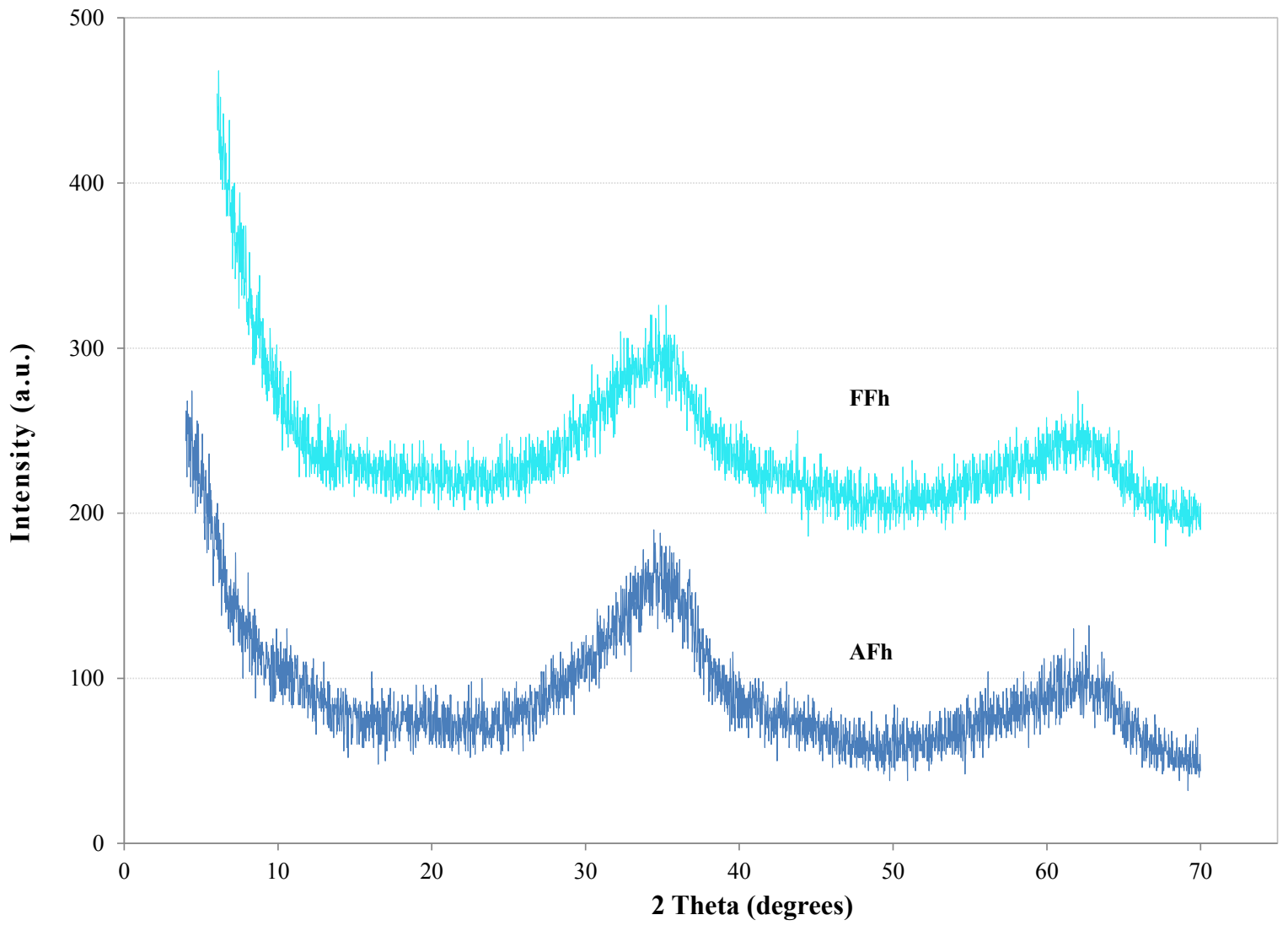

Figure 6. XRD patterns of AFh and FFh.

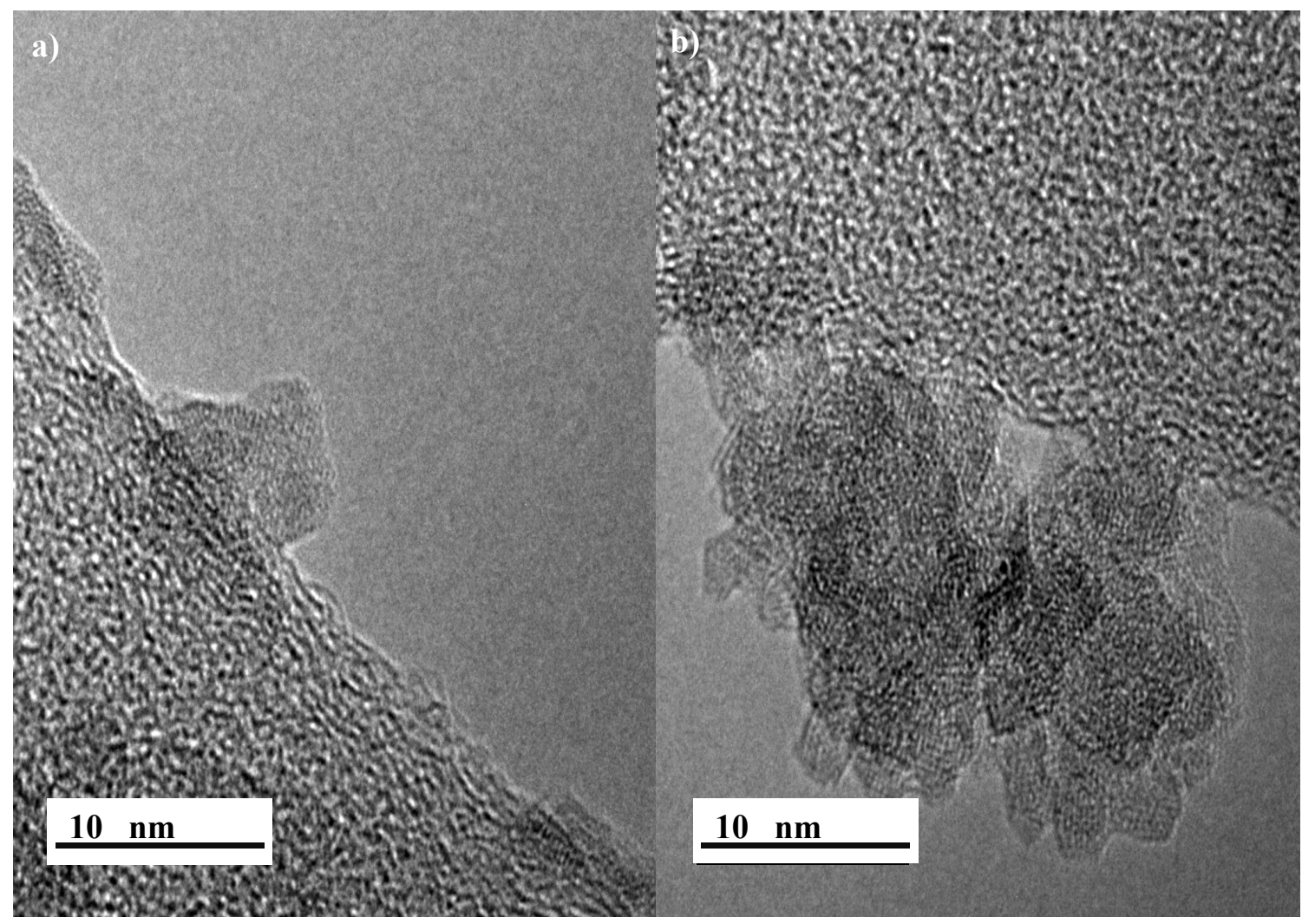

Figure 7. TEM images of (a) AFh and (b) FFh. 
are at best difficult and prone to high uncertainties. Therefore, we believe BET SSA measurements yield a more accurate average picture that relates directly to the sizes present, according to equation (1), and we may use these measurements to investigate more accurately the size difference between both synthesized samples. BET SSA values for our samples were $311 \mathrm{~m}^{2} / \mathrm{g}$ and $258 \mathrm{~m}^{2} / \mathrm{g}$, for FFh and $\mathrm{AFh}$, respectively, which strongly suggest a definitive size difference between the samples.

However, as stated before, the obtained BET SSA values are indicative of the exposed surface area of the dry aggregates, not of the individual particles, and do not reflect the SSA values expected under aqueous suspension. To approach the latter, we used the relationships reported by Wang et al. (2013) between particle size and phosphate adsorption capacity, and in turn between the latter and BET SSA of a series of ferrihydrites, to cross-calculate the relationship between particle size and BET SSA of our ferrihydrites. The linear relationship obtained is shown in Figure 8, and we may interpolate our BET SSA values, to obtain particle sizes of 3.4 and $4.2 \mathrm{~nm}$ for FFh and AFh, respectively.

A cautionary note should be mentioned that the data for the above linear relationship were reported together for FH samples of both 2 lines and 6 lines. If, from these size measurements, we back-calculate the SSA of the individual particles expected, using the specific mass gravity of $3.56 \mathrm{~g} /$ $\mathrm{cm}^{3}$ and a spherical shape (Villalobos and Antelo, 2011), we obtain values of 494 and $400 \mathrm{~m}^{2} / \mathrm{g}$ for individual particles of FFh and AFh, respectively.

\subsubsection{Attenuated Total Reflectance-Fourier Transform Infrared (ATR-FTIR) Spectroscopy}

Ferrihydrite identification was also attained by ATRFTIR spectroscopy, which shows the characteristic bands for this material as reported previously by Hausner et al. (2009), and no major distinction between the FFh and AFh (Figure 9). Three predominant regions may be identified in the spectra: (i) near $3150 \mathrm{~cm}^{-1}$ the $\mathrm{O}-\mathrm{H}$ stretching signals appear in a very broad band, related to structural hydroxide as well as adsorbed $\mathrm{H}_{2} \mathrm{O}$; (ii) between 1650 and $1300 \mathrm{~cm}^{-1}$, deformation water bending vibrations appears near 1630 $\mathrm{cm}^{-1}$, and the asymmetric and symmetric stretching of C-O from adsorbed carbonate may be observed at 1465 and $1345 \mathrm{~cm}^{-1}$, respectively (Bargar et al., 2005; Hausner, et al., 2009); (iii) Fe-O lattice stretching modes appear at 705, 565,480 and $420 \mathrm{~cm}^{-1}$. However, factors such as the degree of crystallinity and extent of particle aggregation have all been shown to influence the infrared spectrum of iron oxide minerals, and therefore for 2-line ferrihydrite those signals are not well defined (Hausner et al., 2009).

\subsection{5. $\mathrm{Cr}$ (VI) Adsorption}

Maximum chromate adsorption was evaluated at $\mathrm{pH} 4$. As with goethite, the solid concentrations were set to achieve similar aqueous concentrations of surface area between the

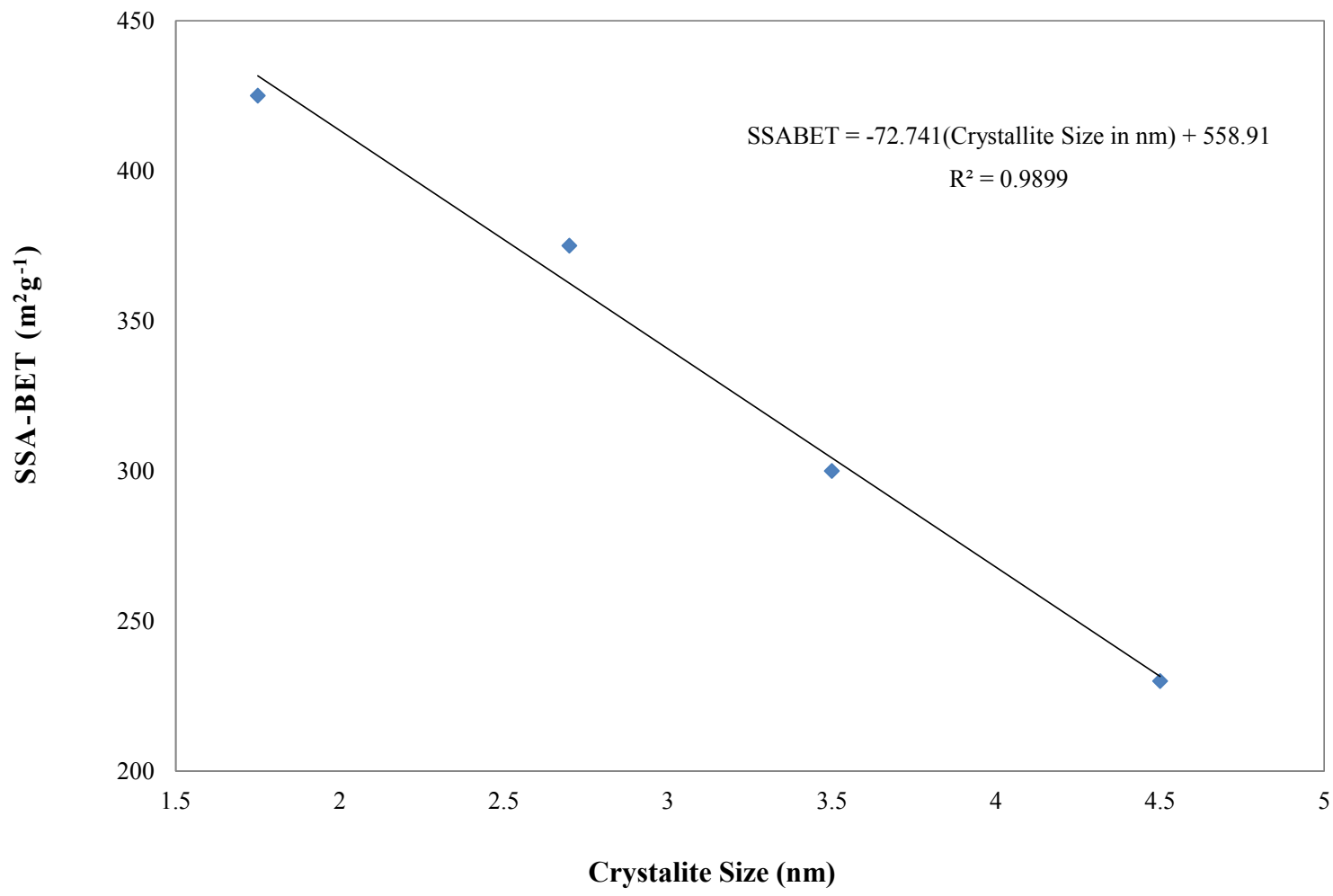

Figure 8. Linear relationship between particle size and BETSSA, recalculated from data by Wang et al. (2013). 


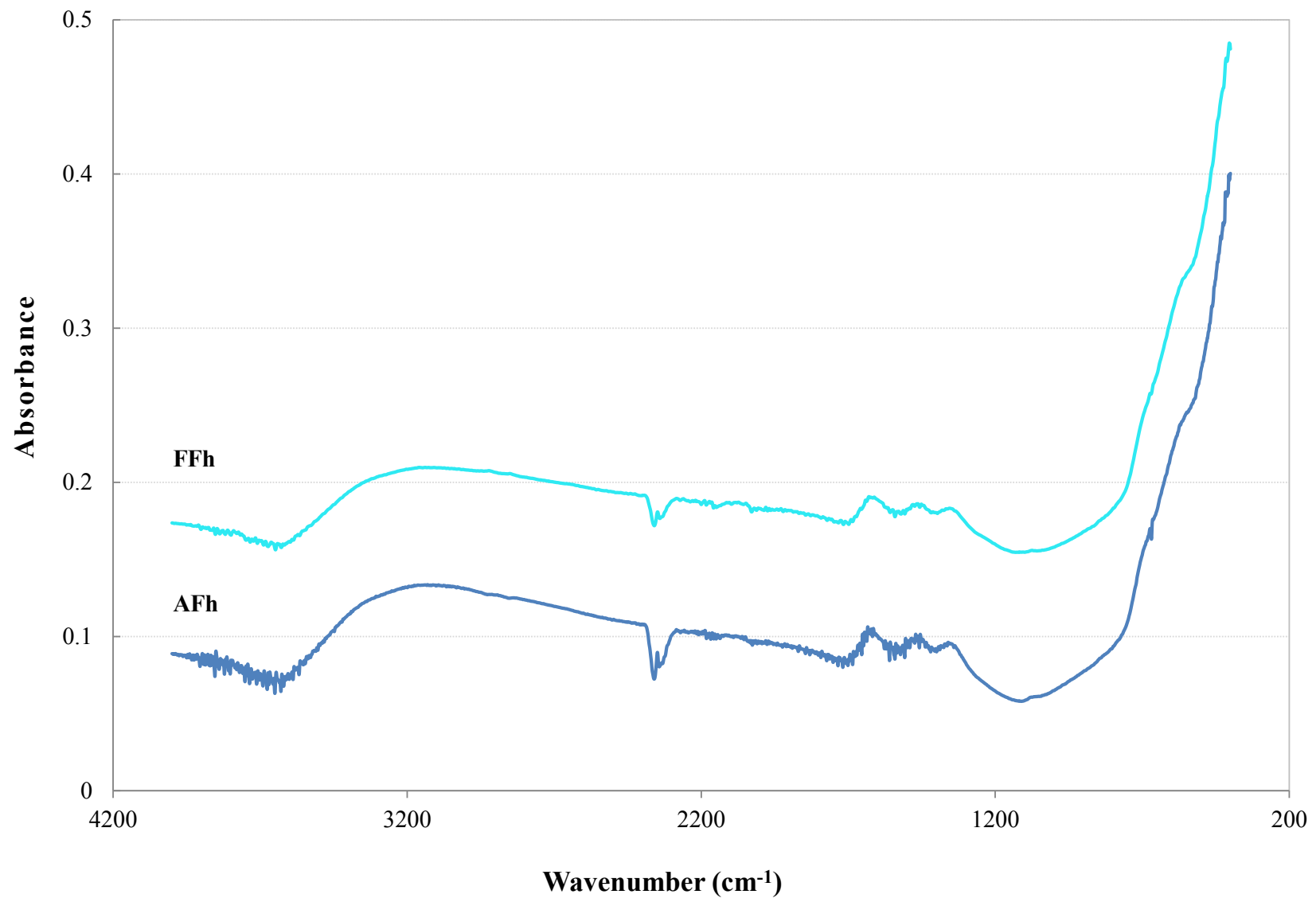

Figure 9. ATR-FTIR spectra of FFh and AFh.

two minerals. The results are shown in mmol of $\mathrm{Cr}(\mathrm{VI})$ adsorbed per gram of ferrihydrite (Table 5). Surprisingly, both yield very similar values of $0.97-1.05 \mathrm{mmol} \mathrm{g}^{-1}$. In this case, it is not accurate to normalize by experimental surface area because of the strong aggregation during the BET analysis. However, if we use the back-calculated SSAs from the linear relationship previously found ( $c f$. section 3.4.3) (Wang et al., 2013), of 400 and $494 \mathrm{~m}^{2} / \mathrm{g}$ for AFh and FFh, respectively, we obtain values of 2.43 and $2.12 \mu \mathrm{mol} \mathrm{m}^{-2}$ for $\mathrm{AFh}$ and FFh, respectively. These values suggest that the surface of the aged sample is more reactive than that of the fresh sample, i.e., larger FH particle sizes are more reactive, which is an unexpected result, but shows a similar trend as for goethite. Nevertheless, this needs to be confirmed through other adsorption measurements, for example by acid-base titrations to obtain proton adsorption data.

\section{Conclusions}

The rate of $\mathrm{OH}$ - addition to the $\mathrm{Fe}\left(\mathrm{NO}_{3}\right)_{3}$ solution was the crucial factor to synthesize goethite of different particle sizes - the higher the rate, the larger the resulting particles. Under rate-controlled conditions we were able to synthesize
Table 5. Maximum $\mathrm{Cr}(\mathrm{VI})$ adsorption onto ferrihydrite. $[\mathrm{Cr}(\mathrm{VI})]$ initial $=$ $4 \times 10^{-3} \mathrm{M}, \mathrm{I}=0.1 \mathrm{M} \mathrm{NaClO}_{4}$ at $\mathrm{pH} 4$.

\begin{tabular}{cc}
\hline Sample & $\begin{array}{c}\mathbf{C r}(\mathbf{V I}) \\
\left(\mathbf{m m o l ~ g}^{-1}\right)\end{array}$ \\
\hline FFh & $1.05 \pm 0.02$ \\
AFh & $0.97 \pm 0.01$ \\
\hline
\end{tabular}

goethite with specific surface areas (SSAs) ranging from ca. $40 \mathrm{~m}^{2} \mathrm{~g}^{-1}$ to $100 \mathrm{~m}^{2} \mathrm{~g}^{-1}$. We confirmed that as SSA decreases (i.e., particle size increases), the surface reactivity of the goethite particles increased, when adsorbed concentrations are reported per surface area. For ferrihydrite, we found that the aging time at the synthesis $\mathrm{pH}$ of 7.5 was the most important factor to control the final particle size. Indirect calculations yielded particle sizes obtained of 3.4 and $4.2 \mathrm{~nm}$ for freshly prepared and 48-h aged ferrihydrite, respectively.

\section{Acknowledgements}

The authors wish to thank Dr. Teresa Pi Puig at the Geology Institute - UNAM for the X-ray Diffraction measurements, Dr. Lucy Mora Palomino at the Geology 
Institute - UNAM for access to ultracentrifuge, freezer and lyophilizer equipment, and Dr. Jesús Ángel Arenas Alatorre, for his guidance in preliminary TEM images of ferrihydrite. We thank students and technicians from LABQA at the Chemistry School, UNAM for their help with handling the analytical equipment and techniques. M. V.-G. and K. V.-E. are grateful to the CONACyT and Senescyt for the Ph.D. student fellowships received. M. U.-A. thanks the CONACyt for the Master's student fellowship received. This project was funded by UNAM-PAPIIT Project IT100912. Finally, we appreciate the comments from two anonymous reviewers who helped improve the manuscript for publication.

\section{References}

Adegoke, H.I., Adekola, F.A., Fatoki, O.S., Ximba, B.J., 2013, Sorptive Interaction of Oxyanions with Iron Oxides: A Review: Polish Journal of Environmental Studies, 22, 7-24.

Akiyama, E., Markworth, A.J., McCoy, J.K., Frankel, G.S., Xia, L., McCreery, R.L., 2003, Storage and release of soluble hexavalent chromium from chromate conversion coatings on $\mathrm{Al}$ alloys - Kinetics of release: Journal of the Electrochemical Society, 150, B83-B91.

Antelo, J., Avena, M., Fiol, S., Lopez, R., Arce, F., 2005, Effects of pH and ionic strength on the adsorption of phosphate and arsenate at the goethite-water interface: Journal of Colloid Interface Science, 285, 476-486.

Antelo, J., Fiol, S., Pérez, C., Mariño, S., Arce, F., Gondar, D., López, R., 2010, Analysis of phosphate adsorption onto ferrihydrite using the CD-MUSIC model: Journal of Colloid and Interface Science $347,112-119$.

Atkinson, R.J., Posner, A.M. and Quirk, J.P., 1967, Adsorption of potentialdetermining ions at the ferric oxide-aqueous electrolyte interface: The Journal of Physical Chemistry, 71, 550-559.

Bargar, J.R., Kubicki, J.D., Reitmeyer, R., Davi, J.A., 2005, ATR-FTIR characterization of inner-sphere and outer-sphere carbonate surface complexes on hematite: Geochimica et Cosmochimica Acta, 69, $1527-1542$.

Burrows, N., Hale, C., Penn, L., 2013, Effect of pH on the kinetics of crystal growth by oriented aggregation: Crystal Growth and Design, 13, 3396-3403.

Childs, C.W., 1992, Ferrihydrite: A review of structure, properties and occurrence in relation to soils: Zeitschrift für Pflanzenernährung und Bodenkunde, 155, 441-448.

Cudennec, Y., Lecerf, A., 2006, The transformation of ferrihydrite into goethite or hematite, revisited: Journal of Solid State Chemistry, 179, 716-722.

Fendorf, S., Eick, M.J., Grossl, P., Sparks, D.L., 1997, Arsenate and Chromate Retention Mechanisms on Goethite. 1: Surface Structure: Environmental Science \& Technology, 31, 315-320.

Fortin, D., Langley, S., 2005, Formation and occurrence of biogenic ironrich minerals: Earth-Science Reviews, 72, 1-19.

Granados-Correa, F., Corral-Capulin, N.G., Olguin, M.T., Acosta-Leon, C.E., 2011, Comparison of the Cd(II) adsorption processes between boehmite (gamma-AlOOH) and goethite (alpha-FeOOH): Chemical Engineering Journal, 171, 1027-1034.

Guo, H.B., Barnard, A.S., 2013, Naturally occurring iron oxide nanoparticles: morphology, surface chemistry and environmental stability: Journal of Materials Chemistry A, 1, 27-42.

Guyodo, Y., Mostrom, A., Penn, R.L., Banerjee, S.K., 2003, From Nanodots to Nanorods: Oriented aggregation and magnetic evolution of nanocrystalline goethite: Geophysical Research Letters, 30, 191-194.

Hausner, D.B., Bhandari, N., Pierre-Louis, A. M., Kubicki, J. D., Strongin, D. R., 2009, Ferrihydrite reactivity toward carbon dioxide: Journal of Colloid and Interface Science, 337, 492-500.
Hiemstra, T., 2013, Surface and mineral structure of ferrihydrite: Geochimica et Cosmochimica Acta, 105, 316-325.

Hiemstra, T., van Riemsdijk, W.H., 1996, A surface structural approach to ion adsorption: The charge distribution (CD) model: Journal of Colloid and Interface Science, 179, 488-508.

Hofmann, A., van Beinum, W., Meeussen, J.C.L., Kretzschmar, R., 2005, Sorption kinetics of strontium in porous hydrous ferric oxide aggregates II. Comparison of experimental results and model predictions: Journal of Colloid and Interface Science, 283, 29-40.

Jaiswal, A., Banerjee, S., Mani, R., Chattopadhyaya, M.C., 2013, Synthesis, characterization and application of goethite mineral as an adsorbent: Journal of Environmental Chemical Engineering, 1, 281-289.

Kosmulski, M., Durand-Vidal, S., Maczka, E., Rosenholm, J.B., 2004, Morphology of synthetic goethite particles: Journal of Colloid and Interface Science, 271, 261-269.

Li, Z., Zhang, T., Li, K., 2011, One- step synthesis of mesoporous two-line ferrihydrite for effective elimination of arsenic contaminants from natural water: Dalton Transactions, 40, 2062-2066.

Livi, K.J.T., Villalobos M., Varela M., Villacís-García M., Vaca-Escobar K., Sverjensky D.A., 2013, The relationship of goethite surface structure, habit and adsorption capacity (abstract), in Goldschmidt Conference 2013: Florence, Italy, Goldschmidt, 1.

Maji, S.K., Pal, A., Pal, T., 2008, Arsenic removal from real-life groundwater by adsorption on laterite soil: Journal of Hazardous Materials, 151(2-3), 811-820.

Michel, F.M., Ehm, L., Antao, S. M., Lee, P. L., Chupas, P. J., Liu, G., Strongin, D.R., Schoonen, M.A.A., Phillips, B.L., Parise, J.B., 2007, The structure of ferrihydrite, a nanocrystalline material: Science, 316(5832), 1726-1729.

Mesuere, K., Fish, W., 1992, Chromate and oxalate adsorption on goethite. 1. Calibration of surface complexation models: Environmental Science \& Technology, 26, 2357-2364.

Montes-Hernandez, G., Beck, P., Renard, F., Quirico, E., Lanson, B., Chiriac, R., Findling, N., 2011, Fast precipitation of acicular goethite from ferric hydroxide gel under moderate temperature (30 and 70 degrees C): Crystal Growth \& Design, 11, 2264-2272.

Parks, G.A., 1990, Surface energy and adsorption at mineral-water interfaces: An introduction, in Hochella, M.F.Jr., White, A.F. (eds.), Mineral-Water Interface Geochemistry: Chantilly - USA, Mineralogical Society of America, 23, 133-175.

Perelomov, L.V., Pinskiy, D.L., Violante, A., 2011, Effect of organic acids on the adsorption of copper, lead, and zinc by goethite: Eurasian Soil Science, 44, 22-28.

Prasad, P.S.R., Shiva Prasad, K., Krishna Chaitanya, V., Babu, E.V.S.S.K., Sreedhar, B., Ramana Murthy, S., 2006, In situ FTIR study on the dehydration of natural goethite: Journal of Asian Earth Sciences, $27,503-511$.

Rout, K., Mohapatra, M., Anand, S., 2012, 2-line ferrihydrite: synthesis, characterization and its adsorption behaviour for removal of $\mathrm{Pb}(\mathrm{II}), \mathrm{Cd}(\mathrm{II}), \mathrm{Cu}(\mathrm{II})$ and $\mathrm{Zn}(\mathrm{II})$ from aqueous solutions: Dalton transactions, $41,3302-3312$.

Ruan, H.D., Frost, R.L., Kloprogge, J.T., 2001, The behavior of hydroxyl units of synthetic goethite and its dehydroxylated product hematite: Spectrochimica Acta Part a-Molecular and Biomolecular Spectroscopy, 57, 2575-2586.

Salazar-Camacho, C., Villalobos, M., 2010, Goethite surface reactivity: III. Unifying arsenate adsorption behavior through a variable crystal face - Site density model: Geochimica et Cosmochimica Acta, 74, 2257-2280.

Schwertmann, U., Cambier, P., Murad, E., 1985, Properties of goethites of varying crystallinity: Clays and Clay Minerals, 33, 369-378.

Schwertmann, U., Cornell, R.M., 2007, Iron Oxides in the Laboratory: Preparation and characterization: Weinheim, Wiley-VCH Verlag GmbH., X p.

Schwertmann, U., Stanjek, H., 1998, Stirring effects on properties of Al goethite formed from ferrihydrite: Clays and Clay Minerals, 46, 317-321.

Schwertmann, U., Stanjek, H., Becher, H.-H., 2004, Long-term in vitro transformation of 2-line ferrihydrite to goethite/hematite at 4,10 , 
15 and $25^{\circ} \mathrm{C}$ : Clay Minerals, 39, 433-438.

Swedlund, P.J., Webster, J.G., Miskelly, G.M., 2009, Goethite adsorption of $\mathrm{Cu}$ (II), $\mathrm{Pb}$ (II), $\mathrm{Cd}$ (II), and $\mathrm{Zn}$ (II) in the presence of sulfate: Properties of the ternary complex: Geochimica et Cosmochimica Acta, 73, 1548-1562.

Van Geen, A., Robertson, A.P., Leckie, J.O., 1994, Complexation of carbonate species at the goethite surface - implications for adsorption of metal-ions in natural-waters: Geochimica et Cosmochimica Acta, 58, 2073-2086.

Varanda, L.C., Morales, M.P., Jafelicci, M., Serna, C.J., 2002, Monodispersed spindle-type goethite nanoparticles from Fe-III solutions: Journal of Materials Chemistry, 12, 3649-3653.

Villacís-García, M., Villalobos, M., Gutiérrez-Ruiz, M., 2015, Optimizing the use of natural and synthetic magnetites with very small amounts of coarse $\mathrm{Fe}(0)$ particles for reduction of aqueous $\mathrm{Cr}(\mathrm{VI})$ : Journal of Hazardous Materials, 281, 77-86.

Villalobos, M., Antelo, J., 2011, A unified surface structural model for ferrihydrite: Proton charge, electrolyte binding, and arsenate adsorption: Revista Internacional de Contaminación Ambiental, $27,139-151$

Villalobos, M., Cheney, M.A., Alcaraz-Cienfuegos, J., 2009, Goethite surface reactivity: II. A microscopic site-density model that describes its surface area-normalized variability: Journal of Colloid and Interface Science, 336, 412-422.

Villalobos, M., Leckie, J.O., 2001, Surface complexation modeling and FTIR study of carbonate adsorption to goethite: Journal of Colloid and Interface Science, 235, 15-32.
Villalobos, M., Perez-Gallegos, A., 2008, Goethite surface reactivity: A macroscopic investigation unifying proton, chromate, carbonate, and lead(II) adsorption: Journal of Colloid and Interface Science, 326, 307-323.

Wang, X., Li, W., Harrington, R., Liu, F., Parise, J.B., Feng, X., Sparks, D.L. 2013, Effect og ferrihydrite crystalite size on phosphate adsorption reactivity: Environmental Science and Technology, 47, 10322-10331.

Weidler, P.G., Schwinn, T., Gaub, H.E., 1996, Vicinal faces on synthetic goethite observed by atomic force microscopy: Clays and Clay Minerals, 44, 437-442.

Zamiri, R., Ahangar, H.A., Zakaria, A., Zamiri, G., Bahari, H.R., Drummen, G.P.C., 2014, Hydrothermal synthesis of goethite (alpha-FeOOH) nanorods in the presence of ethylenediamine:thiourea: Journal of Nanoparticle Research, 16, 2332-2342.

Zhang, J.S., Stanforth, R., 2005, Slow adsorption reaction between arsenic species and goethite (alpha-FeOOH): Diffusion or heterogeneous surface reaction control: Langmuir, 21, 2895-2901.

Manuscript received: November 18, 2014

Corrected manuscript received: March 9, 2015

Manuscript accepted: March 20, 2015 